\title{
The Contribution of E-Procurement on Business Operations of Road Maintenance Fund (RMF), Rwanda
}

\author{
Alphonse MUGEMA ${ }^{1}$ and Dr. Khan Jean de Dieu \\ HAKIZIMANA ${ }^{2}$ \\ ${ }^{1,2}$ School of Business and Economics, Mount Kenya University, \\ Kigali, Rwanda
}

\begin{abstract}
This study examined the contribution of eprocurement on business operations in Rwanda using a case of Road Maintenance Fund. The study determined the effects of electronic tendering, electronic-sourcing electronic auctioning. A descriptive research design was adopted. The targeted population was 148 employees and beneficiaries of RMF. A sample of 109 respondents calculated using Slovene's formula was selected using and adequate sample design consisting of purpose sampling technique and simple random sampling technique were helpful in selecting workers. Information from workers were obtained using a questionnaire survey, while information from key informants were collected using interview guide. Quantitative information was analyzed using Statistical Package for Social Sciences version 25.0 through the presentation of data in Tables, Figures, and Percentages Frequencies. Inferential statistical was used to reflected correlation and regression analysis. Qualitative data was analyzed using content analysis through themes and subthemes. The study indicated that e-tendering $(r=0.372, p=0.000)$, esourcing $(\mathrm{p}=0.257, \mathrm{p}$ value $=0.001)$ and $\mathrm{e}$-auctioning $(\mathrm{p}=0.168, \mathrm{p}$-value $=0,002)$ are predictors for business operations' performance. It is recommended to establish mechanisms to copy with constraints impending the implementation of e-procurement. Automated procurement must be clear for requisition, tendering contractual agreement and payment, adopt the user friendly data method that all contractors could use to improve their internal processes to reduce bureaucracy and increase efficiency. Similar research may be undertaken to discover whether similar findings would be realized.

Keywords: Electronic Procurement, Tendering, Sourcing, Auctioning, Performance, Business Operations
\end{abstract}

\section{Introduction}

According to Dean and Lang (2018), governments have different choices to finance their actions and follow their financial and fiscal policy. These choice comprise the application of e-procurement, cost recovery and user charges, property and investment income, sale of government assets (like the sale of public enterprises and domestic and foreign grants). According to RPPA Official Website, the Rwandan government through RPPA (Rwanda Public Procurement Authority) has implemented the way to address manual procurement practices where every business and public entities are asked to have the electronic procurement in order to avoid bad practices which may bring corruption in the period of procurement process. By end of each phase, the law will apply to every public institution in Rwanda. This research will mainly put much emphasis to the importance of application of e-procurement in government institutions.

Procurement is pertinent in promoting business operations to the public. However, there are constraints that affect their performance. Business operations are vulnerable to corruption which leads to waste, reduced service quality, inefficiency and ineffectiveness, sub standards goods, services and works (McCormack, 2010).

In search of ways to improve business operations, public procurement techniques (e-tenderingsourcing, e-sourcing, e-auctioning) was very pertinent in confirming farness in expenditures of public to procure goods and services that lead to the establishment of anti-corruption entities to copy with this issue with little success. It is also noted that many European and Asian economies had well executed national e-procurement systems for buying goods and services for all government. 
In Rwanda, Ruhigira (2019) conducted a survey on role of public procurement in organization service delivery in Rwanda using a case of Kigali teaching hospital and noted that the hospital is dedicated to eprocurement implementation, e-procurement is influenced by information technology, staff training and supplier capacity. Rwanda Public Procurement Authority [RPPA] (2019) reported that eprocurement positively influenced procurement performance at RPPA. E-procurement is crucial because it transformed the formerly looked down traditional function into competitive tool. He noted the internet through e-procurement had made eprocurement effective and efficient thus influencing procurement performance in Rwanda.

The above studies did not focus on e-procurement processes in term of e-tendering, e-sourcing and eauctioning on performance of business operations for public procurement in Rwanda. Informed by this knowledge gap, this is majorly aimed to answer these questions: To what extend have e- tendering, esourcing and e-auctioning been implemented in Road maintenance fund? What is the effect of e- tendering, e-sourcing and e-auctioning on performance of business operation of Road Maintenance Fund?

The research objectives were:

(i)To determine effects of e- tendering on business operations of Road Maintenance Fund in Rwanda.

(ii)To assess effect of electronic-sourcing on business operations of Road Maintenance Fund in Rwanda,

(iii)To analyze the effects of electronic auctioning on business operations of Road Maintenance Fund in Rwanda..

\section{Review of Literature}

A research conducted by Mose et al. (2013), revealed that e-tendering contributed to reduced cycle times, enhances compliance to legal and regulations, enhanced working costs and time management, enhance accuracy, transparency and integrity in the procurement processes.

Kasyoki (2014) argued that tendering refers to the procedure for seeking provides for supply of goods and services and disposal of adequate where an invitation is enlarged and provides are made and taken into consideration based on pre-determined assessment criteria, prior to the creation of a contractor for the supply of goods and services. The study carried out by Kiage (2013) evidenced that etendering is of great importance to organizations for cost savings and business improvements it reforms the way organizations conduct their procurement procedure. The use of e- tendering by organizations
ISSN 2455-6378

improves quality that in turn improves the level of output (Neef 2010).

A study carried out by Banjoko (2010). evidenced that e-procurement effectiveness benefits comprise benefits of the increased control over supply chain, proactive management of key data and higher quality purchasing decision in the organization (Banjoko, 2010). Owino and Korir (2010) stated that the benefits of e-tendering are reduced purchasing cycle a time and cost, improved budgetary control achieved through limited spending and improved reporting facilities, elimination of administrative mistakes, increasing buyers productivity facilitating them on strategic purchasing associated with problems, reducing prices via price standardization and consolidation of buyers, improvement, improvement of information management, better to prices form alternative suppliers and summaries of spending.

According to Raymond (2018), e-tendering is linked with the reduction of operational cost, increased adequacy, increasing agreement respect, reducing cycle time and decreased cost for inventories and effectiveness

According to Raymond (2018) electronic sourcing represents a key adoption of e-procurement; esourcing provide the accessibility while, Wild (2015) states the advantages that indicate owing to the adoption of e-sourcing use comprises of increased time for sourcing and procuring, increase administrative procedure, eliminating administrative mistakes and expenses, improved buyer productivity, reducing prices via product standardization and merging purchasing power , suitable information management, increased commercial interactions with suppliers, improved budgetary control and decreasing maverick purchases.

By dynamically stimulating this collaborations, e- In this evolving e-commerce conditions, once of critical challenges to supply chain managers is assessment of value and effect of e-commerce systems on their companies (Snow, 2013). As procurement had matured and processed so have the associate tools and services available to organizations (Caroline, 2011).

According to Kamotho, (2014) the development in number of suppliers, internet access and development need to manage the bottom line are creating a perfect condition for more Indian firms to jump into the auction bandwagon. Forward auctions tools the form of single seller providing an item for sale, with buyer's competition to secure the item by bidding the price upward. Thus, the winning bidder is seller who provides the lowest price, reverse auctions are most adopted for procuring goods and services by private organizations, governmental institutions and non-profit organizations (Wyld, 2012). 
Kiage (2013) argued that Electronic auction technologies and e-markets are emerging as the critical infrastructure of modern web-enabled organizations. The internet and world wide web provides a cost effective strategy for entities in search, negotiation, coordination, business and cooperation in their supply www is being utilized to incorporate business across traditional business entities restrictions to establish an extended companies for their partners. Jensen et al. (2018) indicated that manager's coaching behaviors had a positive influence on employee's view of their work execution and quality of service.

Sajuyigbe (2012) suggested that the electronic recording system allowed employees to finish and present their data in time. Thus, the study strongly recommended training, supervision, and control on records and the board aptitudes for all employees in the association so as to improve execution.

\section{Materials and Methods}

A descriptive research design was utilized owing to the fact it is in helpful in labelling features of wide population, using a wider sample size. This research design adopt a standardized questionnaire where the consistency of information is assessed. The researcher used a mix method. Creswell (2013) specifies that the target population is a combination of words utilized to describe the total quality of cases of the type that are subject the research. The target population for this study contained $148 \mathrm{RMF}$ workers and beneficiaries who were set into departments like, procurement department and other different categories of staff were chosen and this facilitated to discover how various departments conduct the e-procurement operate and to obtain a diversity of a perceptions on the contribution of e- procurement on business operations in public institutions. Slovin's formula was used to calculate the sample size. Eq (1):

$$
n=\frac{N}{1+N(e)^{2}}
$$

Thus; Where $\mathrm{n}=$ Sample Size, $\mathrm{N}=$ Population Size , and $\mathrm{e}=$ Margin Error $=0.05$

$\mathrm{n}=148 / 1+148(0.05) 2$

$\mathrm{n}=148 / 1+0.37$

$\mathrm{n}=148 / 1.37$

$\mathrm{n}=108.02919708029$

Through the use of Yamane formula above mentioned where $e=0.05, \mathrm{~N}=148$, the sample size become 109.

In selecting respondents, the researcher used stratified sampling, simple random and purposive sampling techniques. Analysis of data involved the procedure of organizing, synthesizing, and searching for significant patterns in the crude information gathered. The information was coded to generate themes which would already been formulated. Data was entered into the SPSS 26.0 for analysis. To establish the relationships under investigation, each concept in the independent variable was correlated with the e-procurement constructs and Pearson's correlation coefficient determined. Regression analyses summed all the dependent variable constructs and regressed against the independent variable. The $R$ (regression coefficient) was utilized to explain the nature and strength of the relationship. A model was provided depending on the outcome of the regression that was further used to quantify the relationship under investigation.

\section{Results}

\subsection{Most Commonly adopted e-procurement processes at Road Maintenance Fund in Rwanda}

Table 4. 1 Most Commonly adopted e-procurement processes at Road Maintenance Fund in Rwanda

\begin{tabular}{|c|c|c|c|c|c|c|c|c|c|c|c|c|c|}
\hline \multirow{2}{*}{$\begin{array}{c}\text { Most Commonly } \\
\text { adopted e- } \\
\text { procurement } \\
\text { processes }\end{array}$} & \multicolumn{2}{|c|}{$\begin{array}{l}\text { Strongly } \\
\text { Disagree }\end{array}$} & \multicolumn{2}{|c|}{ Disagree } & \multicolumn{2}{|c|}{ Not Sure } & \multicolumn{2}{|c|}{ Agree } & \multicolumn{2}{|c|}{$\begin{array}{c}\text { Strongly } \\
\text { Agree }\end{array}$} & \multicolumn{3}{|c|}{ Total } \\
\hline & $\mathbf{N}$ & $\%$ & $\mathbf{N}$ & $\%$ & $\mathbf{N}$ & $\%$ & $\mathbf{N}$ & $\%$ & $\mathbf{N}$ & $\%$ & $\mathbf{N}$ & M & SDV \\
\hline $\begin{array}{l}\text { Adoption of e- } \\
\text { tendering }\end{array}$ & 19 & 17.4 & 9 & 8.3 & 3 & 2.3 & 50 & 46.3 & 28 & 25.7 & 109 & 3.9 & 0.86 \\
\hline $\begin{array}{l}\text { Adoption of e- } \\
\text { sourcing }\end{array}$ & 15 & 13.9 & 12 & 11.8 & 6 & 5.1 & 17 & 15.3 & 59 & 53.9 & 109 & 3.73 & 0.81 \\
\hline $\begin{array}{l}\text { Adoption of e- } \\
\text { auctioning }\end{array}$ & 7 & 6 & 7 & 6 & 0 & 0 & 44 & 41 & 51 & 47 & 109 & 3.92 & 0.72 \\
\hline
\end{tabular}

Source: Researcher, 2020 
The e-procurement adopted is reflected through etendering with $(\mathrm{M}=3.9, \mathrm{SD}=0.86)$, e-sourcing with
$(\mathrm{M}=3.73, \mathrm{SD}=0.81)$, e-auctioning with $(\mathrm{M}=3.92$, $\mathrm{SD}=0.72)$

\subsection{The effects of e-tendering on Business operation performance}

Table 4. 2 Coefficients of e-tendering and business operations performance

\begin{tabular}{ccccc}
\hline Model & $\begin{array}{c}\text { Unstandardized Coefficients } \\
\text { B std.Error }\end{array}$ & $\begin{array}{c}\text { Standardized Coefficients } \\
\text { Beta }\end{array}$ & t & Sig. \\
\hline $\begin{array}{c}\text { (Constant) } \\
1\end{array}$ & .961 .240 & & 4.002 & 0 \\
e-tendering & .779 .058 & 0.754 & 13.435 & 0 \\
\hline
\end{tabular}

a. Dependent Variable: Business Operations' performance

Results shows a regression coefficient of independent variable e-procurement were statistically significant by explaining business operations' performance. It showed e-procurement to be positive towards business operations $(\mathrm{r}=0.754, \mathrm{p}$ value $=.000$. It means that increase in e-procurement by one unit affect positively business operations' performance by 0.754 units.

\subsection{Effects of E-sourcing on Business Operations performance of Road Maintenance Fund}

Table 4.3 Regression, coefficients

\begin{tabular}{ccccrr}
\hline Model & $\begin{array}{c}\text { Unstandardized } \\
\text { Coefficients }\end{array}$ & & $\begin{array}{c}\text { Standardized } \\
\text { Coefficients }\end{array}$ & $\mathrm{t}$ & Sign. \\
\hline B & B & Std.Error & Beta & & \\
\hline 1 & 0.871 & 0.183 & & 4.626 & 0 \\
e-Sourcing & 0.811 & 0.44 & 0.844 & 18.444 .000 \\
\hline
\end{tabular}

a. Dependent variable: Business Operations' performance

Results on e-sourcing were positive in predicting business operations' performance. It showed esourcing to be positive correlated with business operations at $\mathrm{r}=.844, . \mathrm{p}=.000$. Therefore, any change in enables RMF to improve business operations success by .844 units.

\subsection{Effects of e-auctioning on Business Operations' performance at Road Maintenance Fund}

Table 4.4 Regression coefficient

\begin{tabular}{cccccc}
\hline Model & \multicolumn{2}{c}{ Unstandardized coefficients } & Standardized coefficients & $\mathrm{t}$ & Sig. \\
\hline & $\mathbf{B}$ & std.Error & Beta & & \\
\hline $\begin{array}{c}\text { (Constant) } \\
1\end{array}$ & 1.041 & 0.148 & & 7.045 & 0 \\
e-auctioning & 0.771 & 0.036 & 0.778 & 21.409 & 0 \\
\hline
\end{tabular}

a. Dependent variable: Business Operations

Results revealed that independent variable eauctioning are statistically significant in predicting business operations' performance. It showed eauctioning is positively associated with business operations' at $\mathrm{r}=.788, \mathrm{p}=.000$. It means that an increase in e-auctioning by one units enable RMF to improve business operations by .877 . 
4.5. The Overall regression analysis between eprocurement processes and business operations performance
A simple multiple regression model is adopted to test for the correlation between independent variables (Eauctioning, E-Tendering, and E-Sourcing) on business operations.

Table 4. 5 Coefficients between e-auctioning, E-Sourcing, and E-Tendering and business operations' performance

\begin{tabular}{cccccc}
\hline Model & \multicolumn{2}{c}{ Unstandardized coefficients } & Standardized coefficients & $\mathrm{t}$ & Sig. \\
\hline & B & std.Error & Beta & & \\
\hline (Constant) & 0.423 & 0.162 & 0.168 & 2.606 & 0.01 \\
E-Tendering & 0.174 & 0.056 & 0.257 & 3.082 & 0.002 \\
E-Sourcing & 0.247 & 0.07 & & 3.516 & 0.001 \\
E-auctioning & 0.327 & 0.07 & 0.372 & 4.64 & 0 \\
\hline
\end{tabular}

a. Dependent variable: Business Operations Performance

$\mathrm{BOP}=\mathrm{B}+\mathrm{b}_{1} \mathrm{x}_{1}+\mathrm{b}_{2} \mathrm{x}_{2}+\mathrm{b}_{3} \mathrm{x}_{3}+\mathrm{e}$

Information felt that e-tendering is correlated with business operations with an $r=.168, p=.002$. Meaning that any change in e-tendering affect positive business operations. Information argued that esourcing is correlated with the success of business operation with $\mathrm{r}=.257, \mathrm{p}=.001$. It denotes that any adjustment in e-sourcing affect in positive way the success of business operations at RMF. Finally eauctioning has a positive correlation with business operations where by any change in e-auctioning boost the success of RMF by. $372 \mathrm{~g}$ for government and taxpayers

\subsection{Discussion}

The present study corresponds with Dean and Lang (2018) which stated that e-tendering contributes to reduced tendering cycles, enables RMF to comply with rules on procurements, improved labor cost and time management, increased accuracy, transparency and integrity in the procurement processes.

Results from this study concurs with Jensen et al.(2018)) who stated the gains that increase owing to e-sourcing comprises of acceleration of time for procuring goods and services, eliminating administrative mistakes and costs, enhanced buyer productivity, reducing prices via product standardization and consolidation of purchasing power information management, increased commercial correlation with supplier, improved monetary and decreased maverick purchases..

Results correspond with Hult and Kamel (2014) who stated that e-auctioning is a group of application that comprises most of usable functions to assist company in tendering process of purchasing transaction. The use of e commerce system may fortify search ability, enable faster and more accurate that distribution.
This study concurs with Owino and Korir (2010) who These findings concurs to that of Hult and Kamel (2014) who stated that the system will fortify the RMF supplier correlation by giving easy access to information, the bidding process and ensue cost saving for government and taxpayers.

\section{Conclusions}

To the effects of e-tendering on business operations' performance, it was indicated that e-tendering adoption influenced improvement in efficacy, reduction of cycle time, it leads to the reduction of ordering and holding costs, reduction of number of piece of paper uses and enhances organizational cash flow.

With regard to the effects of e-sourcing on business operations' performance, it was concluded that esourcing adoption has fostered time for procuring goods and services, elimination of administrative mistakes and cost, improved buyer productivity, better information management in the procurement department, enhanced commercial interaction with suppliers, improved internal audit and decreased maverick purchases and accelerated time for sourcing and procurement activities

Lastly regarding the effects of e-auctioning on business operations' performance, the study concluded e-auctioning gives data on procured goods and services, paying process and utilizing computer based networks, gives cooperative business where all parties work together and gives the chance to procure goods and services using transparency and efficiency, this facilitated them to comply with rules regulating how goods and services are procured, processed and supplied.. 


\section{Acknowledgments}

I wish to acknowledge Dr. Hakizimana Khan Jean de Dieu for her contribution to this work from the beginning up to it's the completion. I also wish to extend my acknowledgement to the Mount Kenya University Road Maintenance Fund authorities for their support and collaborative in term of data collection.

\section{Reference}

1. Banjoko, S. A. (2010). Production and Operations Management, Lagos: Saban Publishers.

2. Caroline, N. (2011) Inventory Management System and Profitability of Small and Medium Scale Entrepreneurs in Kampala, Unpublished Research Project, Makerere University Uganda.

3. Creswell, J. W. (2013). Qualitative inquiry and research design: Choosing among five approaches. Thousand Oaks, CA: Sage Publications.

4. Dean, D. H., \& Lang, J. M. (2018). Comparing three signals of service quality: Journal of Services Marketing, vol.23, pp. 23-34

5. Hult, M. (2004) Kamel. (2014). SherifKamel, ICT4D - Case of the Information Society in Africa. a proposed article submitted for review for possible publication. Encyclopedia of Information Science and Technology

6. Jensen J.K \& Marie L. Refsgaard (2018), "procurement capacity development: from theory to practice," in Proceedings of the 3rd international public procurement, 28-30

7. Kamotho,D.K, (2014) E-Procurement And Procurement Performance Among State Corporations In Kenya. Unpublished Master of Business Administration, School Of Business, University Of Nairobi

8. Kasyoki J. (2014), Effects of public procurement on the use of donor-funded projects a case of Moi Teaching and Refferal Hospital. International journal of public sector Management, vol 3(10)

9. Kiage, O. J. (2013). Factors Affecting Procurement Performance: A Case of Ministry of Energy. Department of Entrepreneurship Jomo Kenyatta University of Agriculture and Technology.

\section{ISSN 2455-6378}

10. Kothari, C.R. (2013) Research Methodology, Methods and Techniques, Wishwa Prakshan, New Delhi

11. McCormack,K (2010). Challenges facing adoption of electronic procurement in public sector in Kenya: A case of Nairobi Water and Sewerage Company. International Journal of Social Sciences and Entrepreneurship, 1(11), 267-286.

12. Mose, M., Njihia, M..\&Magutu, P. (2013).The Critical Success Factors and Challenges in Eprocurement Adoption among Large Scale Manufacturing Firms in Nairobi, Kenya. European Scientific Journal, 9(13)

13. Neef, J, (2010). Operations management. New Delhi, prentice-hall.

14. Owino, W. \& Korir, J. (2010). Public health sector efficiency in Kenya: estimation and policy implications. Nairobi: Institute of Policy Analysis and Research.

15. Rwanda Public Procurement Authority [RPPA] (2019). Annual reports on the use of $e$ procurement in public institutions in Rwanda. Kigali, Rwanda.

16. Raymond, J. (2018). Benchmarking in Public Procurement, Benchmarking an International Journal, vol.15. Iss: 6 pp 782-793.

17. Ruhigira, U.S. (2019). Role of public procurement in organization service delivery in Rwanda: Case study of Kigali teaching hospital. A Bachelor Dissertation at Mount Kenya University. Kigali, Rwanda.

18. Sajuyigbe, A.S (2012). Adoption of e-commerce to Business Operations: A key to Achieving Nigeria Vision 20:2020.The polytechnic, Ibadan, Nigeria.

19. Snow, J. (2013). Procurement Performance Indicators Guide Using Procurement Performance Indicators to Strengthen the Procurement Process for Public Health Commodities.U.S. Agency for International Development.

20. Wild R. (2015). Production and Operations, 5th Ed. London: Cassel.

21. Wyld, D.C. (2012). Reverse Auctions 101. Louisiana: Southeastern Louisiana University 